\title{
Women survivors of intimate partner violence: the difficult transition to independence*
}

\author{
MULHERES SOBREVIVENTES DE VIOLÊNCIA EXERCIDA POR PARCEIROS ÍNTIMOS: A \\ DIFÍCIL TRANSIÇÃO PARA A AUTONOMIA
}

\author{
MUJERES SUPERVIVIENTES DE LA VIOLENCIA EJERCIDA POR SUS PAREJAS: LA DIFÍCIL \\ TRANSICIÓN HACIA LAAUTONOMÍA
}

\author{
Maria Neto da Cruz Leitão'
}

\begin{abstract}
Objective: To understand the trajectories that women go through from entering into to leaving relationships involving intimate partner violence (IPV), and identify the stages of the transition process. Method: We utilized a constructivist paradigm based on grounded theory. We ensured that the ethical guidelines of the World Health Organization for research on domestic violence were followed. The analysis focused on narratives of 28 women survivors of IPV, obtained from in-depth interviews. Results: The results showed that the trajectories experienced by women were marked by gender issues, (self) silencing, hope and suffering, which continued after the end of the IPV. Conclusion: The transition process consists of four stages: entry - falls in love and becomes trapped; maintenance - silences own self, consents and remains in the relationship; decides to leave - faces the problems and struggles to be rescued; (re) balance - (re) finds herself with a new life. This (long) process was developed by wanting (and being able to have) self-determination.
\end{abstract}

\section{RESUMO}

Objetivo: Conhecer as trajetórias que as mulheres percorrem desde a entrada até à saída de relações de violência exercida por parceiros íntimos (VPI), e identificar as fases do processo de transição. Método: Utilizou-se um paradigma construtivista com recurso à grounded theory. Salvaguardaram-se as orientações éticas da OMS em matéria de investigação sobre violência doméstica. A análise centrou-se em narrativas de 28 mulheres sobreviventes de VPI, obtidas em entrevistas em profundidade. Resultados: Referem que as trajetórias percorridas pelas mulheres foram atravessadas por questões de género, (auto) silenciamento, esperança e sofrimento, o que ultrapassou o fim da VPI. Conclusão: O processo de transição é constituído por quatro fases: entrada - enamora-se e fica aprisionada; manutenção - auto-silenciase, consente e permanece na relação; decisão de saída - enfrenta o problema e luta pelo resgate; (re)equilíbrio - (re)encontrase com uma nova vida. Este (longo) processo foi atravessado por querer (e poder) autodeterminar-se.

\section{DESCRITORES}

Violence against women

Spouses

Women's health

Gender and health

Nursing care

\author{
DESCRIPTORS \\ Violência contra a mulher \\ Cônjuges \\ Saúde da mulher \\ Gênero e saúde \\ Cuidados de enfermagem
}

\section{RESUMEN}

Objetivo: Se pretendió conocer las trayectorias que las mujeres recorren desde la entrada hasta la salida de relaciones con violencia ejercida por su pareja (VPI, por sus siglas en portugués) e identificar las fases del proceso de transición. Método: Para ello, se utilizó un paradigma constructivista, se recurrió al muestreo teórico (grounded theory) y se salvaguardaron las orientaciones éticas de la OMS en materia de investigación sobre violencia doméstica. El análisis se centró en las narrativas, obtenidas en entrevistas en profundidad, de 28 mujeres que sobrevivieron a la VPI. Resultados: Muestran que en las trayectorias recorridas por las mujeres se dieron cuestiones de género, (auto)silenciamiento, esperanza y sufrimiento, una serie de aspectos que se mantuvieron una vez terminada la VPI. Conclusión: El proceso de transición está formado por cuatro fases: entrada, en la que se enamora y se queda atada; manutención, en la que se autosilencia, consiente y permanece en la relación; toma de decisión de salir, en la que se enfrenta al problema y lucha por el rescate, y (re)equilibrio, en la que se (re)encuentra con una nueva vida. Este (largo) proceso se vio influido por el querer (y poder) llegar a la autodeterminación.

\section{DESCRIPTORES}

Violencia contra la mujer

Esposos

Salud de la mujer

Género y salud

Atención de enfermería

* Extracted from the thesis "Mulheres sobreviventes de violência exercida por parceiros íntimos: uma transição sensível a cuidados de enfermagem," Catholic University of Portugal, 2012. ${ }^{1}$ Coordinating Professor, School of Nursing of Coimbra, Coimbra, Portugal 


\section{INTRODUCTION}

Violence affects at least one in three women and girls worldwide, with the abusers usually being someone they know $^{(1)}$. Violence against women is any act of genderbased violence that results in, or could result in, physical, sexual or psychological damage or suffering, including threats of such acts and coercion or arbitrary deprivation of liberty, whether occurring in public or private life ${ }^{(2)}$. The objective of these actions is intimidation, punishment, humiliation, and maintenance of stereotypical roles linked to gender, or impeding women from having human dignity, sexual autonomy, and physical, mental and moral integrity while also undermining their personal safety, self-esteem or personality, or reducing their physical and/or intellectual capacities.

Power differences, discriminatory cultural norms and economic inequalities have been used to deny the human rights of women and perpetuate violence, which is assumed to be one of the major ways by which men maintain their control over women's ability to act and sexuality ${ }^{(3)}$. Violence continues to be a widespread violation of the human rights of women and remains one of the main obstacles to achieving gender equality. Most survivors/ victims suffer in silence and do not seek help.

Intimate partner violence (or violence in intimate relationships) is a type of violence that is normally perpetrated by intimate male partners and which causes physical, sexual or psychological injury or suffering in women. This violence can be exercised by husbands, partners, ex-husbands, ex-partners or other men who maintain or have maintained intimate relationships with the women in question ${ }^{(4)}$.

IPV is a global phenomenon found in all human societies; women are not free from this type of violence in any country or culture. The ubiquity of this kind of violence, which knows no borders, transcends cultures and encompasses all social classes, is rooted in the patriarchal system and in the systemic domination of women by men. It has imprisoned women in (un)affectionate relationships, where everything stays in-house, covered up and protected by intimacy. The doors of (un)awareness have been opening this domain, which has been traditionally closed, hidden and concealed, silent and silenced(5).

The overall concept of violence in couples refers to a series of distinct phenomena that have different causes and different trajectories ${ }^{(6)}$. There are three types of violence that are organized around issues of power and controlling relationships: (a) intimate terrorism, involving a larger pattern of coercive control that integrates intimidation, emotional abuse, economic abuse, isolation, minimization, denial and guilt, and using children and the assertion of male privilege in order to terrorize survivors/ victims. It's what most often produces injuries and health effects in the long term; (b) violent resistance, involving the use of violence by survivors/victims to resist the situation or as a defense when faced with a situation of greater severity. The objective of this violence is not controlling partners or relationships. For some women it is an instinctive reaction when they suffer an attack and acs almost without thinking; (c) situational violence in couples, which is the product of conflict or tension within relationships that requires one or two elements to react with violence. It may be smaller, isolated acts or a recurrent, chronic problems in which one or both partners resort to violence as a way of expressing their extreme anger or frustration ${ }^{(5)}$.

This investigation focuses on IPV perpetrated on women by their intimate partners, defining it as a set of abusive behaviors intentionally perpetrated by men, usually on a continuous basis; it may involve physical violence (e.g., physical and sexual abuse) and non-physical violence (e.g., forms of control, omissions).

At the end of the twentieth century, IPV was recognized as one of the greatest risks to public health ${ }^{(6)}$, demonstrating itself nationally and internationally as an issue that involves losses for personal well-being and the safety of communities. The literature shows high convergence in the nature of IPV, as well as its prevalence and impact on women's health. The results of a transnational study ${ }^{(7)}$ identified rates of continued physical violence that ranged between $13 \%$ and $61 \%$, while in the majority of the places studied it ranged between $23 \%$ and $49 \%$; the prevalence of sexual violence ranged between $6 \%$ and $59 \%$, while in the majority of locations it ranged between $10 \%$ and $50 \%$; and $20 \%$ to $75 \%$ of women had experienced one or more acts of psychological violence. Abusive relationships were marked by subordination and intimidation, commonly silenced by inequalities in gender relations, leading to selfsilencing, becoming invisible, and extending over long periods of time, during which the violence often is not recognized even by survivors.

The results of different investigations converge and show that sharing life with men who perpetrate violence on their partners may have profound impact on the health of women, whether it be in the short, medium or long term ${ }^{(4)}$.Violence also has a negative (or very negative) impact on physical and mental development, as well as sexual and reproductive health. Additionally, consumption of tobacco and alcohol on the part of victims/survivors of violence can be considered a risk factor for a wide range of diseases ${ }^{(4,8)}$.

The International Council of Nurses $(\mathrm{ICN})^{(9)}$ recognizes the importance of IPV and reinforces the idea that societal tolerance in the face of abuse has contributed to the existence of such behaviors; in many societies abuse of women is understood as an acceptable behavior and is justified as a normal and routine part of married life.

We understand the importance of knowing the contributions that nursing can make and what interventions are being undertaken by nurses to help women survivors
Women survivors of intimate partner violence: the difficult transition to independence Leitão MNC 
of IPV find new ways of living and being themselves, in order to reshape their self-identity and rebuild their life without IPV. It is important to know the trajectories experienced by these women, not only from entering into to leaving relationships -- which has already been studied -but throughout the transition process from entrance into relationships to the reconstruction of life without IPV.

Knowing that Meleis considers transition as a central and relevant concept in the nursing discipline that has contributed to its stability ${ }^{(10)}$, we therefore tried to understand the processes of transition as experienced by women survivors of IPV. According to one study ${ }^{(11)}$, transition is a process of passage during which people redefine their sense of self and begin to develop new individual actions in response to disruptive life events. Transitions require from people a capacity to incorporate new knowledge, in order to change behaviors and even to change the definition of themselves in the social context ${ }^{(10)}$.

The central focus of nursing is to facilitate transitions in the lives of people, families and communities, with the objective that the experiences lived in these processes will promote health and wellness ${ }^{(10)}$.

\section{METHOD}

We chose grounded theory, as this methodology allows us to explore social processes in human interactions and is assumed to be a methodological approach that has its roots in symbolic interactionism ${ }^{(12)}$. This methodological approach seeks knowledge of the perception or meaning of a given situation or object, i.e., how people define events and how they act in relation to their beliefs. Thus, it becomes useful in situations of a psychosocial nature, allowing researchers to obtain details about phenomena such as feelings, thought processes and emotions that are difficult to extract or understand through more conventional research methods ${ }^{(12-13)}$.

We searched for theoretically useful cases and this led us to select participants due to the information they could provide us regarding the subject of study -- transitions to lives without IPV. Access to participants was obtained formally through two offices/healthcare centers for victims of violence in central Portugal. Other women survivors of IPV came to us informally, by way of the snowball method, because knowledge the interviewees had of other women permitted access to new participants.

Since this was a qualitative study, it was not our objective to include a large number of cases, but rather to select the cases according to their potential, that is, in order to gather conditions of information and sharing that made it possible to develop insights in the study area. Therefore, we established as a principle the diversification of women and opted for the criterion of theoretical saturation, finishing when new aspects related to the essence of the phenomenon stopped arising ${ }^{(12)}$.
Knowing that IPV is occurs across all ages, sociocultural strata and educational levels, we selected a theoretical sampling that allowed us to include women survivors of IPV derived from different geographical contexts -- more rural and more urban- with a wide range of ages, educational levels, sociocultural strata, professions and marital statuses. We included women with few to many years in their intimate relationships, years of IPV, and zero to several children.

All information was obtained from semi-structured, in-depth interviews. We chose to conduct narrative interviews because we wanted to know the trajectories of the intimate relationships in which IPV occurred. To this end, we needed the participants to provide a narration of their life trajectories from entering into to leaving violent relationships, following with restructuring that they may have had to undergo. A semi-structured interview was chosen because its objectives are clear and well-defined. We developed a script in order to help us keep the objectives in mind. This was adjusted during the process of gathering the information; we added indicators for going in-depth, specifically when tabulating the information, while not changing the essence of the original document.

The data collection occurred between June 2008 and September 2010. Direct access to the participants for conducting the interviews was negotiated with each after we knew they were available to participate in the study. The women who were in follow-up at the victim healthcare offices/centers were previously informed by the center technicians. Initial contacts were made by phone and/or email. We scheduled in-person interviews for the day, time and place that was most convenient for each participant.

Although the entire process of collecting and analyzing information occurred simultaneously, there were times when we paused for more careful analysis of the findings that we had identified, in order to rethink and redefine the direction to be followed. The study was conducted in three stages: 1 . in-person narrative interviews of 16 women who had decided to leave their abusive relationships and for which most had sought help; 2 . in-person narrative interviews of 15 women who had already left abusive relationships and claimed that they were living a new phase of their lives; 3 . interviews to validate the analysis of the findings and collection of more information on two areas that we were not been able to understand based on the analysis of the information already gathered. These interviews were conducted with women interviewed in the second stage. Twenty-eight survivors of IPV participated in the study and only three women participated in all three stages of data collection.

The collection of information was carried out entirely by the researcher. A Free and Informed Consent form was always delivered initially along with a written invitation to participate, which included identification of the investigator, the study objectives, the safeguard of voluntarily agreeing to participate and the freedom to withdraw at 
any stage of the process, even after consent was given. After authorization by the participants, all interviews were recorded on magnetic media, which was transcribed in computerized form, with each participant being assigned a fictitious name.

We followed all the guidelines of grounded theory for data analysis concerning open coding, axial coding and selective coding ${ }^{(13)}$. Sorting and analysis of information was performed in a sequential manner, whether or not it overlapped in the collection of information ${ }^{(13)}$. We ended data collection when we reached the point at which we did not find any more categories or subcategories in the interviews that were to be carried out and the properties and dimensions that continued to emerge were not considered sufficiently relevant to the characterization of the respective categories or subcategories already defined.

We believed that a stage had been reached where we could integrate and relate the different categories. In order to organize the interrelationships among the different categories we needed to find the core category, i.e., identify the main category of the investigation. We built diagrams that would serve us for reviewing the internal consistency and refining the transition process. Wanting to (and being able to) have self-determination was selected as the central category.

With regard to rigor in information analysis, emphasis was placed on heterogeneity and contextual knowledge, not on interpretation and generalization of the results. We sought to use the utmost rigor and for this, so we had to use some of the criteria that we had been following throughout the process. With regard to arrangement and analysis of information, we followed the audit trails, that is, we created informational material to demonstrate the developed procedures and choices made, which allowed for the possibility of other researchers reconstructing the process that led us to the conclusions, which are present in several examples throughout the text and in the attachment.

The second criterion referred to the validity of the interpretations. Several strategies were developed in order to achieve this validation by the participants regarding the analysis that we were developing: after each interview we presented the participants with the results of analysis of the previous narratives; including the validation of frameworks on the trajectories of women survivors of violence perpetrated by intimate partners: patterns and phases, for all the women who participated in the second period of information gathering; interaction with the collection and analysis of information, reading of formal and informal literature and discussion of the interpretations with other researchers.

It is important to highlight that the validation of the methodology for collection and analysis was performed with two international experts in the field of nursing and IPV- multiple classifications- which allowed for the valida- tion of the different categories that characterized the trajectories and the transition process, the verification of the internal logic of each category and their relationship, the concepts, the properties and the dimensions of each.

The study included 28 women, all Caucasian and of Portuguese nationality, residing in different districts; most of them (21) lived in urban areas. The educational levels of these women were distributed between the 1st cycle, where the largest number ${ }^{(9)}$ were found, and 2 were nearing completion of a doctorate. Their ages ranged between 23 and 62 years and the average was 42 years. Regarding marital status, the majority of women ${ }^{(11)}$ were living separate from the aggressors, but were in the process of divorce. Ten women lived alone with children and 8 lived with their abusers and children; of the remaining women, 3 were married and 3 were in divorce proceedings. It should be noted that these women, regardless of marital status, had already decided to terminate/leave their relationships, with some preparing to exit while others continued to live with their abusers because they had no other place where they could live with their children. Twentythree women had children; the majority ${ }^{(9)}$ had one child. The others were divided into two groups: 7 had two children and 7 had three or more children. Regarding the number of abortions, we found that 16 women had had at least 1 abortion and 2 had had four or more abortions. Regarding religion, 24 women considered themselves to be Catholic, although almost half ${ }^{(11)}$ mentioned that they were not practicing. Up to the time of the study, 19 of the subjects had only experienced one intimate relationship and the others ${ }^{(9)}$ had had two intimate relationships. Of the 9 women who had experienced two intimate relationships, it must be noted that all had experienced situations of violence during their first relationships and 3 were victims/survivors in both relationships.

We could not refrain from safeguarding the ethical principles required in all research processes. Bearing in mind the complexity and sensitivity of the problem under study and the violence that these implications could cause in these situations of violence against women and survivors of IPV - increasing their fragility and accentuating their vulnerability - we sought to protect their human rights and safeguard the principle of non-maleficence in all decisions we had to make. We were aware of the fact that collection of this information by way of interviews could increase the fragility of the participants, particularly when certain issues or events were approached, such as acts of aggression that put their lives at risk, relationship ruptures, and removal from their homes and family breakdowns.

In these situations we tried to respect their wishes, and always hoped that we could make referrals to existing resources in the community that seemed to be the most appropriate. For women who were being supported by health care centers, guidance was given in conjunction with the centers. With regard to the close
Women survivors of intimate partner violence: the difficult transition to independence Leitão MNC 
and personal relationships between the researcher and the participants, which the interviews often led to: while knowing the susceptibilities of the women, we identified issues that required therapeutic, social, legal and safety guidance or interventions.

Knowing that nursing research seeks to combine the principle of rigorous research with genuine concern for the welfare of the participants, we sought to ensure the accuracy of the information collection and later we provided the guidance that we considered to be the most suitable for each woman. In order to help in this process, we relied on the technical expertise of the local support centers for women victims. Whenever we considered it to be appropriate, and while respecting the wishes of the women and upon request for and acceptance of their cooperation, we referred the women to the Coimbra delegation of the Portuguese Association for Victim Support (APAV, as per its acronym in Portuguese).

Simultaneously, we respected the principle of autonomy, seeking to obtain informed consent from all participants and respecting their decisions. To this end, we ensured that the participants had adequate and sufficient autonomy in relation to the investigation; we ensured that they were able to understand this information and had the ability to choose freely and voluntarily to agree or decline to participate. When these conditions were ensured, we asked the women to show and state in writing their willingness to participate in the study, by reading and signing a declaration in duplicate in safeguarding all rights of self-determination, freedom and identity. In regards to the principles of charity and justice, the confidentiality of all participants was always honored. Pseudonyms were assigned to ensure that when the results were disclosed the participants could not be identified.

In summary, we complied with the recommendations of the International Council of Nurses (ICN) ${ }^{(9)}$ and the World Health Organization $(\mathrm{WHO})^{(14)}$ on ethics and security in investigations relating to domestic violence: the safety of the participants; protection of confidentiality for the safety of the women and the quality of data; implementation of the actions necessary to reduce the harm caused to participants; and assumption of the ethical obligation for correct data interpretation and the use of results for policy development and implementation of appropriate measures.

\section{RESULTS}

In this (long) journey of life, we can see that entrance into relationships with IPV were very subtle and almost always unidentified, while the trajectories are assumed to be complex processes. For most participants it was very difficult to identify and (re)conceptualize, to assume and manage.

The 28 participants lived in intimate relationships with different types of violence expressed in different ways: physical, psychological and sexual. We observed that 22 participants reported that violence began while dating; they did not identify the signals at the time, specifically because the violence was essentially psychological, highlighting control, jealousy and verbal attacks, and sexual, expressed through pressure to become sexually active and/or perform unwanted sexual behaviors. We can see that at the dating stage of the relationship physical violence was less frequent, only mentioned by three women, and almost all said they were subjected to psychological violence.

After the start of cohabitation, violence became widespread in different forms --physical, psychological and sexual- with only one participant reporting not ever being sexually abused, while 27 women were targets of all three types of violence from their intimate partners. The most common, rarely identified as such but mentioned by most as the most difficult to bear, was psychological violence that no one sees and leaves no visible marks. That was what caused those moments to be considered the most difficult to accept. Psychological violence was also determined to be the most devastating, since many participants took years to recognize it and identify it as violence. The number of years that women experienced IPV ranged from 2 to 37 years. The average number of years of IPV experienced by these women was 16 years.

The transitions of these women developed in four stages: entry, maintenance, decision to exit and (re)balance. This process can be divided into two distinct periods: the first includes the entry phase and maintenance of the IPV, and the second begins with the decision to exit the relationship and ends with the (re)balance achieved with the reconstruction of their identity. The disruptive decision to leave their relationships is recognized as a milestone in women's lives.

In the first period the women lived two conflicting realities: one was the idealization of intimate relationships sustained by the fantasy of romantic love and marriage. The other was the disappointment in the relationships and the IPV. The first was fueled by the desire for the partners to change or by the hope that they would be able to change themselves. This attitude made it so that they did not identify (stage of entry) or devalue the IPV (maintenance), although it was part of and changed their lives. Moving on to the maintenance phase meant that they identified the IPV but did not want to tell others, which made them stifle themselves and choose to keep the abuse a secret. Their lives became centered on management of the IPV, making it so that they actively submitted themselves to the will of their partners and were depersonalized. Sometimes they felt an inner strength that was questioning their life situations and continuing the relationships because they felt they were going to exhaust their capabilities and their relationship maintenance strategies, without success.

In the second period- the decision to exit and the process of (re)balancing - the women began to direct their 
thoughts towards beginning another direction for their lives, while beginning to re-conceptualize the meanings and the events surrounding their relationship with IPV. As a result of various events (often related to their children and their safety) and specifically in respect to themselvesusually in solitude- they assumed the responsibility for changing their lives and decided to leave the relationships, starting a process of physical and emotional separation, whether or not it was while living in the same household as their partners. They had now begun the fourth and last stage- (re)balance- where they resisted and fought for their independence, while reconstructing their identity. The last phase -- (re)balance ---- was a significantly difficult time, because the IPV almost always continued (and was often more severe), now in conjunction with single parenthood and the reconstruction of new lives, with very little social support. Although it was very difficult, experiences of autonomy increased self-confidence, helping the women reclaim the identities they had lost, and begin manifesting them in new ways of life. They finally felt they could materialize it.

The four phases were sequential, but were not watertight or linear, nor were they exclusive. What happened in a certain phase unfolded and continued into the nextphase. It was a lengthy process- ranging between four and 39 years from entry to (re)balance- and developed as a spiral, more or less tightly wound around wanting to (and being able to) have self-determination in lives free of IPV. The overriding significance of this transition was the conversion, translated by transformation, which led to reconstruction of the meaning of the women's lives and their identities.

The transition process was restricted and constrained by gender issues that sustained inequalities and compromised the process of human development -- from entry to (re)balance -- obtained with reconstruction of the sense of self. It was typically a long journey, lived with ambivalence and much suffering, which required a lot of strength, a lot of courage, and a lot of self-determination; not only to survive throughout the process and decide to leave, but also to achieve this exit and to resist restarting a phase initially marked by more violence, with less security and more economic and social difficulties of various kinds. But the strong desire for, or perhaps the necessity of, being fulfilled and living in peace helped them fight for years, not only against their aggressors, but also against the sociocultural ties that trapped them within themselves and in their broader social contexts, which for many were also very violent.

As socially, well integrated young women, they had become girlfriends (and/or wives), while they became trapped and found themselves to be victims/survivors of a relationship with IPV. Finally, they had to be strong in order to support not only the IPV, but also violence sustained in strong pillars of gender. However, all the experiences lived were the driving force behind changes in the lives of the women, the way it was assumed, how they were integrated and how they responded, in fact, echoed in the way they developed the transition

\section{DISCUSSION}

The knowledge obtained in this study of Portuguese women who survived IPV converges with results from studies conducted during the last decade, both nationally and internationally. This convergence refers specifically to: the manifestations and types of violence suffered; the meanings and expectations of love and intimate relationships; and characteristics of the trajectories of change experienced by the women - phases or stages.

The IPV was felt by many participants to be privatization of structural, cultural and symbolic violence against women. That is, there was permanent guilt for what did not make any sense, subjection to devaluation and constant humiliation; shame and humiliation about their experiences; indifference to the oppression and the oppressed person; use and modification of their bodies to calm their partners and decrease the violence, a reality that they also observed in their progenitors and in many female friends. The theories of patriarchy and romantic love seem to be intertwined, triggering and favoring the maintenance of women in relationships with IPV ${ }^{(15)}$.

In the first phase - entry - they fall in love and are trapped. Relationships of love/intimacy appeared as something more important than the well-being of these women, which seems to have influenced their expectations and their desire not only to initiate, but also to continue to invest in the success of their relationships, in order for them to obtain the desired gains. The non-recognition and/or devaluation of IPV as a problem was influenced by shame, and fear of revealing what they lived/felt and being misunderstood or humiliated by others ${ }^{(16)}$, which led to progressive isolation and immobilization. As they continued not to identify IPV as a problem, the women presented ambivalence in respect to the need for change, therefore remaining in a phase of connection ${ }^{(17)}$ and precontemplation $^{(18)}$. At this stage women invested everything they could to keep their relationships and developed every effort to make the relationships work out, in order to avoid conflicts and prevent other instances of IPV(17). To that end they yielded to the demands of their partners, hoping that love would overcome the problems they felt ${ }^{(19)}$ up to that point, and many had not yet identified the problems as IPV ${ }^{(16)}$. Staying in the relationships was not a problem due to the passivity of the women, but one of many elements that composes the system of beliefs that shapes gender inequalities and produces meanings, expectations and specific behaviors ${ }^{(20)}$.

In the second phase - maintenance - the self is silent, consents and remains in the relationship. The women identified the IPV, took it, consented, silenced themselves, and now
Women survivors of intimate partner violence: the difficult transition to independence Leitão MNC 
(self) managed it, controlling and looking to minimize it. They did not want to believe what they were experiencing and sometimes denied the IPV incidents ${ }^{(17-18.21)}$. This minimization enabled them to reduce the magnitude of the problem and made it difficult for them to adopt behaviors of change.

In the third phase - the decision to leave - the woman faces the problem and fights for redemption. This stage began as a process of awareness, slow and gradual, which led to analysis of gains and losses arising from their relationships, moving toward two choices: to keep or to abandon the relationships ${ }^{(20,22)}$. They wanted to be free and masters of themselves. They felt alienated and lost, alone. They felt an intrinsic need for self-realization and selfrespect. This was structural and foundational for them to return to being worthy of themselves and of their lives. These needs were incompatible with the maintenance of the relationships ${ }^{(17.22-23)}$. The decision to exit and the abandonment of the relationships were the strategies chosen by all participants. But they had to continue to resist the violence: IPV, stalking, and structural and symbolic violence ${ }^{(24)}$. Now they began to be more diverse, and often more intense and generalized.

In the fourth and final phase - (re)balance - the woman resists violence and (re)constructs a new life in freedom. The logistical constraints of rebuilding new families alone, often with children, coupled with more intense IPV, made them at times almost lose control of the situation ${ }^{(17,23)}$. Some could not handle it and returned to their relationships, after apologies and requests made by their partners ${ }^{(16,18,21)}$. They returned only to leave once again. On the second, third and/or fourth attempt they managed to resist and have definitively stayed away from the relationships involving IPV. The demands of daily life and the struggle for independence in rebuilding a new life forced them to establish boundaries, develop assertiveness skills and reclaim and maintain their own territory. They also managed to increase their ability to take risks ${ }^{(22)}$. Each decision, achievement and success functioned as a strengthening agent so that these women could remain firm and therefore could tell everyone (ex-partners, families, society in general and also themselves): I can do it! Self-efficacy was enhanced and also assumed to be particularly important during this process ${ }^{(16,18)}$.

These results support models in which battered women are seen as active survivors instead of helpless victims, because with or without help, they persisted in the relationships until their perceptions regarding the chances of saving the relationships had exhausted, demonstrating their power and creative survival strategies within the IPV. They chose to end the relationships and ask for help when the IPV increased and became a more acute problem. In other words, they increased their efforts and their seeking of assistance as the intensity of the IPV increased ${ }^{(19)}$.

From everything mentioned about the trajectories traveled by women survivors of IPV, we can say that the results obtained in this study have many similarities and convergences with the processes and/or models presented in other studies ${ }^{(16-17,21-22,24-26)}$.

\section{CONCLUSÃO}

Based on the transition concept in nursing, this investigation mapped the transition experienced by women survivors of intimate partner violence (IPV), which is a global health emergency and a chronic issue with strong clinical and social ramifications. Considering that nurses occupy a strategic position for promoting and facilitating healthy transitions, we sought to know the paths that women go through from entering into to leaving relationships involving intimate partner violence (IPV) and identify the stages of the transition process from the experiences lived by women survivors.

The results indicated that the process of transition for these women developed in four phases: entry - the dream lived during the process of falling in love and the disillusionment that imprisoned them; maintenance the emptiness and abandonment experienced in the process of self-silencing and consent which kept them in the relationships; decision to leave - the desire to set themselves free which made them face the problem and fight for self-redemption; and (re)balance - the (re)encounter with their own selves, resulting in the very difficult process of rebuilding a new life of freedom. This process was developed by wanting to (and being able to) have self-determination, and sustained by three pillars: wanting to be free; find meaning in life; and (re)constructing their identities.

As a process, this path was not linear. It was identified as an oscillatory motion, complex, often exhibiting periods of stagnation, deviations and sometimes even regressions. But in all this, if we are speaking of suffering, we must also talk about the dream, the hope and the struggle. All this in order to be a woman with the right to self-determination - living (or not) in an intimate relationship - and to be able to enjoy what she is entitled to as a person and what others have been stealing from her for years: to be able to fulfill her humanity and her freedom, so she can assume the conduction of her life.

In addition to the importance of the issues studied, the adequacy of the methodological options and the fact that we managed to achieve the objectives that we set out for ourselves, we assume that certain limitations may have influenced the results obtained in this study, which we believe it is necessary to reflect upon. We would like to highlight the fact that most of the information collected was retrospective, implying that the participants reconstructed their paths and life stories, which were very long in most situations and were the cause of much suffering. This may have been an impediment to remembering all the facts, meanings, knowledge and feelings present dur- 
ing the whole process in detail. To reduce this limitation, we included women who had recently made the decision to exit their relationships and were still living with IPV. We believe that this limitation can be overcome with longitudinal studies with women survivors of IPV, although it seems it would be difficult, not only to identify, but also to achieve collaboration by, these participants in the first two phases of the transition process.

The results also allowed us to identify IPV as a violation of the human rights of women. As a postmodern hu-

\section{REFERENCES}

1. Naciones Unidas. Asamblea General. Estudio a fondo sobre todas las formas de violencia contra la mujer: Informe del Secretario General (A/61/122/Add.1). Ginebra; 2006:

2. Naciones Unidas. Asamblea General. Resolución 48/104, del 20 de diciembre de 1993. Declaración sobre la eliminación de la violencia contra la mujer. Ginebra: Naciones Unidas; 1993.

3. Naciones Unidas. Estudio del Secretario General. Poner fin a la violencia contra la mujer: de las palabras los hechos. Ginebra: Naciones Unidas; 2006.

4. Organización Panamericana de la Salud; Organización Mundial de la Salud. Informe mundial sobre la violencia y la salud. Washington; 2002.

5. Johnson MP. A typology of domestic violence: intimate terrorism, violent resistance, and situational couple violence. Boston: Northeastern University Press; 2008.

6. World Health Organization. Family and Reproductive Health. Violence against women: a priority health issue. Geneva: WHO; 1997.

7. World Health Organization. WHO Multi-country study on women's health and domestic violence against women. Geneva: WHO; 2005.

8. Breiding MJ, Black MC, Ryan GW. Prevalence and risk factors of intimate partner violence in eighteen U.S. States/Territories, 2005. Am J Prev Med. 2008;34(2):112-8.

9. International Council of Nurses. Dossier of promoting the fight against violence. Geneva: ICN; 2001.

10. Meleis Al. Theoretical nursing: development and progress. 4th ed. Philadelphia: Lippincott Williams \& Wilkins; 2007.

11. Van Loon A, Kralik D. A self-help companion for the healing journey of survivors of child sexual abuse. Adelaide: Royal District Nursing Service Foundation Research Unit, Catherine House; 2005. man science and practice, nursing should contribute to a scientific awareness capable of promoting human life with its philosophical essence, sustained by knowledge of people and their environment and ethical values that safeguard the human rights of women. For all that is known, we would like to acknowledge that this study is of an exploratory nature with regard to transitions in the life situations of women, which, of course, can create interest for other researchers by providing them with continuity and depth in the many dimensions that were explored.

12. Streuberg HJ, Carpenter DR. Investigação qualitativa em enfermagem: avançando o imperativo humanista. 2a ed. Loures: Lusociencia; 2002.

13. Strauss A, Corbin J. Basic of qualitative research grounded theory: procedures and techniques. 2a ed. London: Sage; 1990.

14. Organización Mundial de la Salud. Dando prioridad a las mujeres: recomendaciones éticas y de seguridad para la investigación sobre la violencia doméstica contra las mujeres. Ginebra: OMS; 2001.

15. Souza PA, Da Ros MA. Os motivos que mantém as mulheres vítimas de violência no relacionamento violento. Rev Ciênc Humanas. 2006;(40):509-27.

16. Burke JG, Gielen AC, MacDonnell KA, O'Campo P, Maman S. The process of ending abuse in intimate relationships. Violence Against Women. 2001;7(10):1144-63.

17. Landerburger KM. Explorations of woman's identity: clinical approaches with abused women. In: Campbell J. Empowering survivors of abuse: health care for battered women and their children. Nwebury Park: Sage; 1998. p.61-9.

18. Prochaska JO, Prochaska JM. Why don't continents move? Why don't people change? J Psychother Integr. 1999;9(1):83-102.

19. Fishwick NJ, Campbell JC, Taylor JY. Theories of intimate partner violence. In: Humphers J, Campbell JC. Family violence and nursing practice. Philadelphia: Lippincott Williams \& WiIkins; 2004. p. 29-58.

20. Anderson DK, Saunders DG. Leaving an abusive partner: an empirical review of predictors, the process of leaving and psychological well-being. Trauma Violence Abuse. 2003;4(2):163-91.

Rev Esc Enferm USP
$2014 ; 48(E s p): 07-15$
www.ee.usp.br/reeusp/ $\quad \begin{aligned} & \text { Women survivors of intimate partner violence: } \\ & \text { the difficult transition to independence }\end{aligned}$


21. Burkitt KH, Larkin GL. The transtheoretical model in intimate partner violence victimization: stage changes over time. In: Murphy CM, Roland D Maiuro RD. Motivational interviewing and stages of change in intimate partner violence. New York: Springer; 2009. p.273-303.

22. Wuest J, Merritt-Gray ML. Not going back: sustaining the separation in the process of leaving abusive relationships. Violence Against Women. 1999;5(2):110-33.

23. Merritt-Gray ML, Wuest J. Counteracting abuse and breaking free: the process of leaving revealed through women's voices. Health Care Women Int. 1995;16(5):399-412.
24. Bourdieu P. A dominação masculina. Oeiras: Celta; 2001.

25. Kearney M. Enduring love: a grounded formal theory of women's experience of domestic violence. Res Nurs Health. 2001;24(4):270-82.

26. Dienemann J, Glass N, Hanson G, Lunsford K. The domestic violence survivor assessment (DVSA): a tool for individual counseling with women experiencing intimate partner violence. Issues Ment Health Nurs. 2007;28(8):913-25.

27. Giles J, Curreen H. Phases of growth for abused New Zealand women: a comparison with other studies. Affilia J Women Soc Work. 2007;22(4):371-84.. 